\title{
Sobre hermenêutica e perspectivas historiográficas
}

\section{On hermeneutics and historiographical perspectives} Antonio Cesar de Almeida Santos

História, teoria e variações

Guilherme Pereira das Neves Rio de Janeiro: Contracapa, 2011. 328 p.

Ao olhar a capa de História, teoria e variações, pensei: é bem a cara do autor do livro. Alguns dias depois, lendo um dos textos da coletânea, minha "abdução peirceana" mostrou-se correta. Minha hipotética afirmação foi confirmada com a leitura do capítulo intitulado "História e método". Nele, o autor, Guilherme Pereira das Neves, explica sua predileção pela pintura Gilles, de Jean-Antoine Watteau - a imagem da capa do livro -, contrapondo-a ao desenho de Paul Klee, Angelus Novus, que Walter Benjamin escolheu para ilustrar sua conhecida tese de 
número nove "sobre o conceito da História". Após referir-se ao "respeito que a trajetória e a obra de Benjamin merecem" - com o que concordamos -, Guilherme Pereira das Neves confessa a sua "dificuldade para enxergar" o que Benjamin vê no desenho de Klee para, em seguida, afirmar que, "num certo sentido, a perspectiva que [Benjamin] expõe sobre a história encontra-se na contramão daquela a favor da qual gostaria de aqui argumentar" (p. 104).

Ainda que viéssemos acompanhando a perspectiva "sobre a história" adotada pelo autor de História, teoria e variações, ele declara estar em busca da compreensão de "nossa consciência histórica" (grifos no original), por intermédio da qual nós nos esforçamos para "encontrar um significado para as vidas que levamos no mundo desencantado que é o nosso" (p. 123). Guilherme Pereira das Neves deixa, assim, explícito seu interesse pela proposta hermenêutica de Hans-Georg Gadamer, com a qual concilia a história das linguagens políticas e a história dos conceitos.

Contudo, é conveniente olharmos para a estrutura do livro, dividido em duas partes e com 12 capítulos que nos permitem acompanhar sua trajetória intelectual e nos convidam ao exercício de uma necessária reflexão sobre a prática da história e o papel do historiador. A primeira parte do livro tem um viés mais teórico e recebeu o nome de "O caminho da reflexão". A divisão, contudo, não é rigorosa, e a segunda parte - "O caminho da aplicação" - traz um conjunto de textos que "procuram girar não só em torno de um certo tipo de história que o autor tem aprendido a praticar, como das dificuldades que encontrou para fazê-lo" (p. 12); quer dizer, a todo o momento, a prática e a reflexão sobre a prática se entrelaçam: o livro é um exercício de teoria e de historiografia.

A trajetória intelectual do autor - expressa na sequência dos capítulos, que seguem uma relativa ordem cronológica - permite perceber como ele fez suas escolhas historiográficas. Nesse percurso, ele mostra - e nós podemos acompanhar - os momentos de crise e de perplexidade que viveu com a disciplina, suas insatisfações e, principalmente, os esforços do pesquisador comprometido em "dominar a teoria e a metodologia da história", que ensina em sua atividade de professor do Departamento de História da UFF desde 1977 (p. 13).

Como mencionado, História, teoria e variações é um convite para refletirmos sobre a prática historiográfica; ao mesmo tempo, apresenta bons textos sobre o Antigo Regime português, sobre a Ilustração luso-brasileira, sobre a constituição do Império e a formação da nação brasileira. São textos que abordam a "cultura e a política no mundo luso-brasileiro", a trajetória de "letrados", o funcionamento de instituições políticas e também discussões sobre "processos educacionais" inseridos entre a segunda metade do século XVIII e as décadas iniciais do século XIX. Todos esses temas são discutidos, como indicamos, a partir de algumas abordagens recentes que, infelizmente, são pouco (e/ou mal) exer- 
citadas entre nós: a história das linguagens políticas e a história dos conceitos. Ressalte-se não ser este o caso aqui, pelo contrário.

Também é preciso dizer que os textos desta coletânea, que cobrem um período que vai da década de 1980 aos dias de hoje, não são todos inéditos. Apenas dois deles ainda não haviam sido dados a público. A providência de agrupar essa produção antes dispersa permite dirigir uma visada sobre parcela importante de um trabalho historiográfico que merece ser melhor conhecido e debatido. Além de uma bem cuidada revisão dos textos, o autor buscou dar ao conjunto a necessária unidade, que está evidenciada, por exemplo, na complementaridade entre o primeiro e o quinto trabalhos: "História: a polissemia de uma palavra", dos anos iniciais da década de 1980, traz uma discussão sobre o confronto entre uma "história-narrativa" pré-Annales e a "história-problema"; "Aquém da história: os Annales aos 80 anos", de produção recente, desenvolve o contexto historiográfico surgido com a "história-problema", avançando sua análise até as novas gerações, quando se buscou introduzir "novamente o estudo da singularidade dos eventos e das personagens, em oposição à presença exclusiva das vastas forças anônimas e impessoais" (p. 100).

Ultrapassada a primeira parte do livro, tem-se contato, de modo mais sistemático, com a prática historiográfica do autor. Especificamente no que diz respeito à aplicação de sua perspectiva sobre a história, exposta em maior detalhe no capítulo sexto - "História e método" -, deve-se destacar que, se entendermos que os argumentos teóricos apresentados poderiam mostrar-se áridos, os textos da segunda parte do livro demonstram, com rara felicidade, as possibilidades de uma abordagem que concilia a hermenêutica de Gadamer com as linguagens políticas e a história dos conceitos.

Para avaliarmos em que medida a hermenêutica constituiu-se nessa atitude metodológica tão valorizada por Guilherme Pereira Neves, precisamos considerar que ela, ao mesmo tempo em que nos concede acesso ao outro, oferece a possibilidade de construirmos nossa própria consciência histórica, ou seja, dá-nos a capacidade de perceber a historicidade dos outros e de nós mesmos. Nesse aspecto, todos os seis últimos textos, fruto dessa atitude, merecem leitura atenta, como a "reflexão" que os precede. Podemos, contudo, destacar os capítulos 11 e 12. Em "O Rio de Janeiro de 1794 no Tribunal das Luzes de Reinhart Koselleck", o autor deixa mais explícito o recurso "à concepção de linguagens políticas, [...] como também ao que se conhece como história dos conceitos" (p. 256). A hermenêutica de Gadamer também está presente nesse estudo que discute a "irradiação das Luzes" e busca uma "compreensão dos universos mentais em que estavam inseridos naturais do Brasil e de Portugal" (idem). Em "Independência e liberdade sem liberalismo: Brasil, c.1777-1870" (texto inédito, escrito em parceria com Lúcia Bastos Pereira das Neves), encontramos outro bem acabado exercício 
de aplicação da Begriffsgeschichte de R. Koselleck, ou melhor, da construção e do uso de uma dada terminologia nos debates em torno da formação ideológica do Império brasileiro. Aliás, não obstante os intensos debates sobre os sentidos de liberdade e de independência, conclui-se que "a experiência dos brasileiros continuava ainda a carecer, quase ao final do século XIX, daqueles processos de politização, ideologização, democratização e temporalização que viabilizaram para outras regiões o ingresso no mundo moderno" (p. 311, grifos no original).

Voltemos a Gilles, a imagem que está na capa do livro e que serve para ilustrar a perspectiva histórica com que Guilherme Pereira das Neves se identifica. Para ele, "o uso do passado já não serve para projetar um futuro para todos"; ao contrário, importa a possibilidade de construirmos a "consciência histórica" de um mundo (revelado pela pintura) que, produto de nossas vidas, é representado por "meio dos eventos e desencontros à nossa volta". Assim, com o exercício consciente da "reflexão histórica", poderemos compreender que, "mesmo no mundo fragmentado que é o nosso, é mais comum a compreensão do que a incompreensão" (p. 122-123). 